\title{
Authors' reply to Moore and Smith and colleagues
}

\author{
Len Doyal emeritus professor of medical ethics ${ }^{1}$, Thomas Muinzer lawyer ${ }^{2}$ \\ ${ }^{1}$ Queen Mary, University of London, UK; ${ }^{2}$ School of Law, Queen's University Belfast, Belfast, UK
}

We are glad that Moore, Hunter's contemporary biographer, agrees with our argument. ${ }^{12}$

Smith and colleagues accept that Byrne wanted to be buried intact. Hunter knew his wishes yet boiled him down to create a skeleton. ${ }^{3}$ Many people at the time were morally outraged (and still are) by body snatching. The authors claim that modern medical ethics exist to protect living people, and that no moral or legal issues are posed by decedents having been opposed to the use of their bodies for medical purposes. This is not so. ${ }^{4}$

They then suggest that respecting Byrne's wishes would deny the importance of studying actual bodily remains for medical progress and would threaten their continued preservation for this purpose. No so. Ordinarily, such exhibits are anonymous, with no knowledge of the explicit burial preferences of decedents. With Byrne we know both. The moral problem is the disrespect for Byrne's memory by continuing to ignore his known wishes. The fact that one or two individuals who share his genetic mutation who have no moral or legal status as "relatives" may now think otherwise is irrelevant. ${ }^{5}$

The authors argue that Byrne's skeleton should be kept and displayed just in case it leads to further medical discoveries.
This is an example of an "anything is possible argument," and we leave readers to contemplate the moral absurdity of this reasoning and the impracticality of its implications (warehouses full of bodies, body parts, and skeletons?). The Human Tissue Act 2004 was created partly to counter just such thinking.

We now have Byrne's DNA, and willing volunteers can participate in further acromegaly research. His skeleton has done enough for medicine. Finally show his memory some respect. Bury what is left of Byrne at sea as he originally wanted.

Competing interests: None declared.

1 Doyal L, Muinzer T. Should the skeleton of "the Irish giant" be buried at sea? BMJ 2011;343:d7597. (20 December.)

Moore W. Byrne's body should disappear beneath the waves. BMJ 2012;344:e550

3 Smith M, Knüsel C, Chamberlain A, Mitchell PD. We cannot change the past, but we can learn from it. BMJ 2012;344:e556.

4 McGuiness S, Brazier M. Respecting the living means respecting the dead too. Oxf $\mathrm{J}$ Leg Studies 2008:23:297-316.

5 Mackay J. Halsbury's laws of England. 2005;50:444, 452, 459-60. 